\title{
Semi-Arid Plantation by Anatolian Black Pine and Its Effects on Soil Erosion and Soil Properties
}

\section{Sezgin Hacisalihoglu*}

Faculty of Forestry, Karadeniz Technical University, 61080 Trabzon, Turkey

\section{A R T I C L E IN F O}

\section{Research Articles}

Received 13 February 2018

Accepted 06 March 2018

Keywords:

Forest soil

Tree plantation

Soil loss equation

Anatolian Black pine

Rehabilitation of semi-arid area

"Corresponding Author:

E-mail: sezgin@ktu.edu.tr

\section{A B S T R A C T}

In this study, the effects of Anatolian Black pine [(Pinus nigra Arn. subsp. pallasiana (Lamb.) Holmboe] plantation on hydro-physical soil properties and soil loss were investigated. This study was carried out on the afforestation field of Anatolian Black Pine in the Gölbaşı district of Ankara province, which is included in the arid and semi-arid regions. Totally 48 soil sample in two soil depth level $(0-20 \mathrm{~cm}, 20-50 \mathrm{~cm})$ were collected from forest (36 soil sample) and barren (control) area (12 soil sample). Hydro-physically important soil properties were analysed [Sand (\%), Silt (\%), Clay (\%), Organic Matter $(\%), \mathrm{pH}$, Field Capacity (\%), Wilting Point (\%), Saturation (\%), Available Water Holding Capacity $(\mathrm{cm} / \mathrm{cm})$ Saturated Hydraulic Conductivity $(\mathrm{cm} / \mathrm{hr})$, Bulk Density $\left.\left(\mathrm{gr} / \mathrm{cm}^{3}\right)\right]$. And soil loss in a unit area by using ABAG (Allgemeine Boden Abtrags Gleichung) model was estimated. Soil properties and soil loss amount relations among the land use group were determined. Topsoil $(0-20 \mathrm{~cm})$ and subsoil $(20-50 \mathrm{~cm})$ properties except subsoil organic matter were significantly affected by land use group. Finally, Significant changes were found for annual soil loss amounts in a unit area. Avarage annual soil loss in planted area was found approximately 5.5 times less than barren area at $0-50 \mathrm{~cm}$ soil depth. Vegetation factor (C) which is one of the most important components of the soil loss equation, has been significantly affected by afforestation in a short period of 40 years and thus it was a variable to reduce to soil loss.

Türk Tarım - Gida Bilim ve Teknoloji Dergisi, 6(4): 500-507, 2018

\section{Yarı Kurak Bir Bölgedeki Karaçam Ağaçlandırmasının Toprak Erozyonu ve Toprak Özellikleri Üzerine Etkileri}

M A K A L E B İ L G İ S İ

AraştırmaMakalesi

Geliş 13 Şubat 2018

Kabul 06 Mart 2018

Anahtar Kelimeler:

Orman toprağ

Ağaçlandırma

Toprak kayıp denklemi

Anadolu Karaçamı

Yarı kurak alan rehabilitasyonu

*Sorumlu Yazar:

E-mail: sezgin@ktu.edu.tr
Ö Z E T

$\mathrm{Bu}$ çalışmada, Anadolu Karaçamı [(Pinus nigra Arn. subsp. pallasiana (Lamb.) Holmboe] ağaçlandırmalarının toprağın hidro-fiziksel özellikleri ile birim alandaki toprak kaybı üzerindeki etkileri araştırılmıştır. Bu çalışma, kurak ve yarı-kurak bölgelere dahil olan Ankara ili Gölbaşı ilçesi Anadolu Karaçamı ağaçlandırma sahasında yürütülmüştür. 2017 yılında, ağaçlandırma sahası içinden 36 ve açıklıktan (kontrol) 12 adet alt (0-2) ve üst (20-50) toprak tan toplam 48 adet toprak örneği alınarak önemli hidro-fiziksel toprak özellikleri [kum (\%), toz (\%), kil (\%), organik madde (\%), pH, tarla kapasitesi (\%), solma noktası $(\%)$, toplam su tutma kapasitesi $(\%)$, alınabilir su tutma kapasitesi $(\mathrm{cm} / \mathrm{cm})$ doygun hidrolik iletkenlik $(\mathrm{cm} / \mathrm{hr})$, hacim ağırlı̆̆ $(\mathrm{gr} / \mathrm{cm} 3)]$ analiz edilmiş ve birim alandaki toprak kayıp miktarları USLE'den modifiye edilmiş ABAG (Allgemeine Boden Abtrags Gleichung) yöntemine göre belirlenmiş, toprak özellikleri ve toprak kayıp miktarları arasında ilişki aranmıştır. Üst toprak $(0-20 \mathrm{~cm})$ ve alt toprak $(20-50 \mathrm{~cm})$ özellikleri, alt topraktaki organik madde dışında, ağaçlandırma çalışmalarından önemli derecede etkilenmiştir. Bunun yanı sıra birim alanlardaki yıllık toprak kaybı miktarı, ağaçlandırma sahasında önemli derecede düşük bulunmuştur. Ortalama yıllık toprak kaybı $(0-50 \mathrm{~cm})$ açık alanda yaklaşık 5,5 kat daha fazla bulunmuştur. Toprak kaybı denkleminin en önemli bileşenlerinden biri olan bitki faktörü (C), 40 yıllık gibi kısa bir süre içerisinde ağaçlandırma çalışmalarından önemli derecede etkilenmiştir ve bu nedenle toprak kaybını azaltan bir değişken olmuştur. 


\section{Introduction}

It is widely known that afforestation efforts have a positive effect on many ecological and environmental features such as climate change, biodiversity, water and soil parameters, in particular. Along with afforestation efforts, atmospheric carbon sequestration potential increases and climate change is reduced (Kreidenweis et al. 2016). Birds, Fungi and soil microbial community respond to afforestation with an increase in species richness (Marquiss, 2006; Xiang et al. 2017). By the plantation efforts, carbon stock potential of the ecosystem can be increased, and soil erosion is reduced (Zhiyanski et al., 2015). Soil degradation or soil loss by erosion is one of the biggest environmental problem comes after the global warming and climate change problems (Costanza and Jorgensen, 2002; IUCN, 2015). Every year, 75 billion tones productive soil is lost on the Global scale (Pimentel and Burgess, 2013).

The concept of soil loss by erosion has may more destructive effects, especially on arid and semi-arid ecosystems (Cornelis, 2006; Rebeca et. al. 2011). It is reported that besides the warming above the normal conditions, the precipitation incapacity and evaporation events, which cause the current water to become scarce enough to put the life of the creatures at risk, are also important influences on the conceptual definition of drought (Kezik and Kocaçınar, 2014). Where annual rainfall less than $300 \mathrm{~mm}$ is arid, annual precipitation is places between $300-600 \mathrm{~mm}$ is defined as semi-arid regions (FAO, 1963; Ürgenç, 1998). A large part of Turkey is classified as arid and semi-arid (Figure 1). Southeastern and Central Anatolia regions are classified as semi-arid regions.

The impact of global warming and climate change will be seen in such as semi-arid regions in the near future. In case of the decline in precipitation and the rise in temperatures that effects already significantly will increase the evapotranspiration that takes place on much higher levels of falling rainfall, and the withdrawal of plants and especially woody species from these areas will accelerate as well as will lead to the formation of completely desertified this area (Kocaçınar et al., 2010). Therefore, it is necessary to protect our existing forests in order to minimize the negative impact of global warming and climate changes on plant communities, especially terrestrial ecosystems in future, and to improve barren areas in arid and semi-arid areas such as the Central Anatolian region by afforestation efforts.

Soil Erosion is significantly affected by the land use pattern (Wu, 2008; Li et al., 2014) and plantation efforts significantly reduce the soil erosion and affect some important quality parameter such as soil organic carbon, organic matter, $\mathrm{pH}$ and electrical conductivity in a unit area (Hacisalihoglu et al. 2017). This is especially vital for semi-arid and arid region ecosystems such as Central Anatolia, which tend to degradation. Together with afforestation efforts carried out by adapting species to these areas, soil degradation process can be significantly slowed down by rehabilitating the areas. Feng et al (2015) reported that forest soil highly effects the soil water content depend on land use. Besides, mulching studies as artificial indicators of the afforestation highly effect soilhydro physical parameters such as bulk density, saturated hydraulic conductivity, wilting point, porosity and soil organic matter (Kakaire et al, 2015). Also, it is reported that semi-arid afforestation has positive effects on soilwater conservation (Guo and Shao, 2013). Therefore, afforestation efforts in arid regions have great importance on soil erosion, which is one of the most important environmental problems of the century (Costanza and Jorgensen, 2002). In Turkey, successful afforestation efforts have been carried out in many areas including arid and semi-arid regions (Figure 2; ÇEM, 2017). Anatolian black pine [(Pinus nigra Arn. subsp. pallasiana (Lamb.) Holmboe] which is a variety of Pinus nigra, is also widely used in the rehabilitation of semi-arid and arid areas such as the Central Anatolian region, while the extreme is a well-adapted species (Çetinkaya and Deligöz, 2012) that distributed naturally in Asia Minor, Turkey.

The main purpose of this research; is to determine the effects of the afforestation on soil loss and soil hydrophysical properties in Anatolian black pine plantation in Central Anatolia. The study area had been used until at the end of the 1970s for pastural purposes and later was afforested by Anatolian black pine [(Pinus nigra Arn. subsp. pallasiana (Lamb.) Holmboe] species.

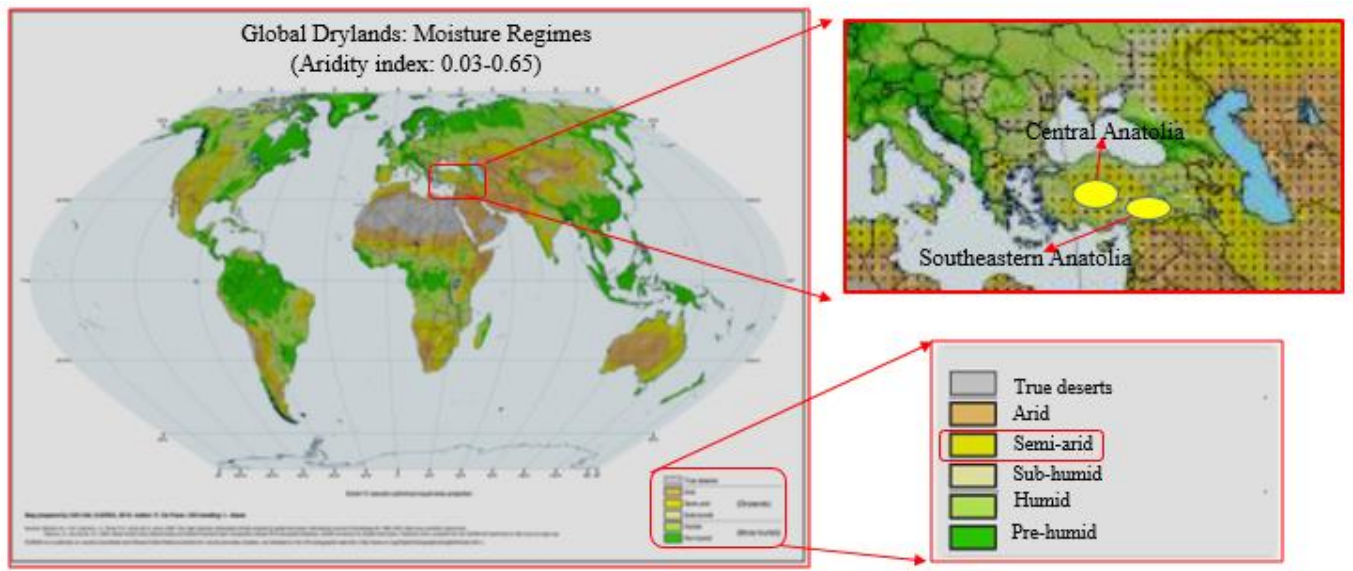

Figure 1 Global Drylands and Dryland in Turkey (Modified from ICARDA, 2010) 


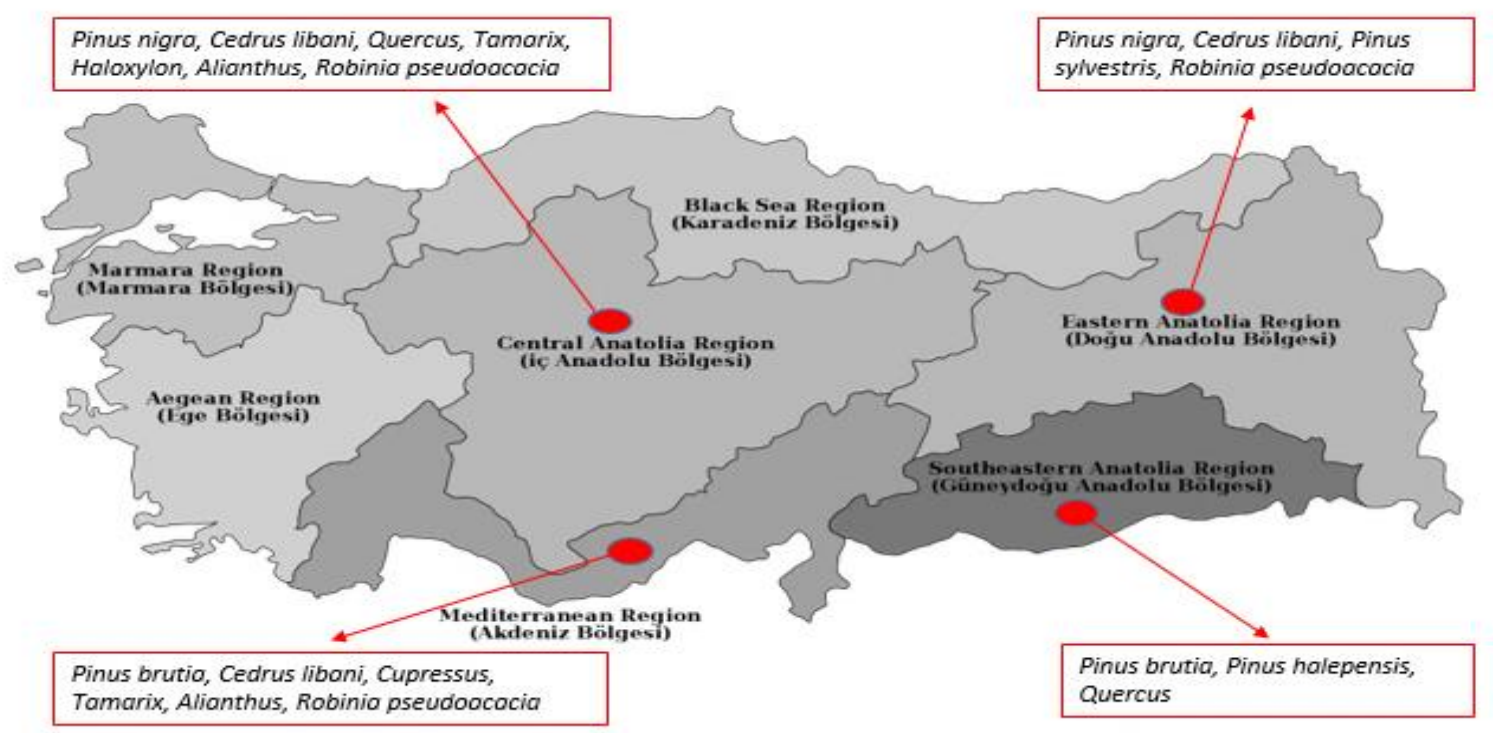

Figure 2 The mostly used tree species in afforestation areas

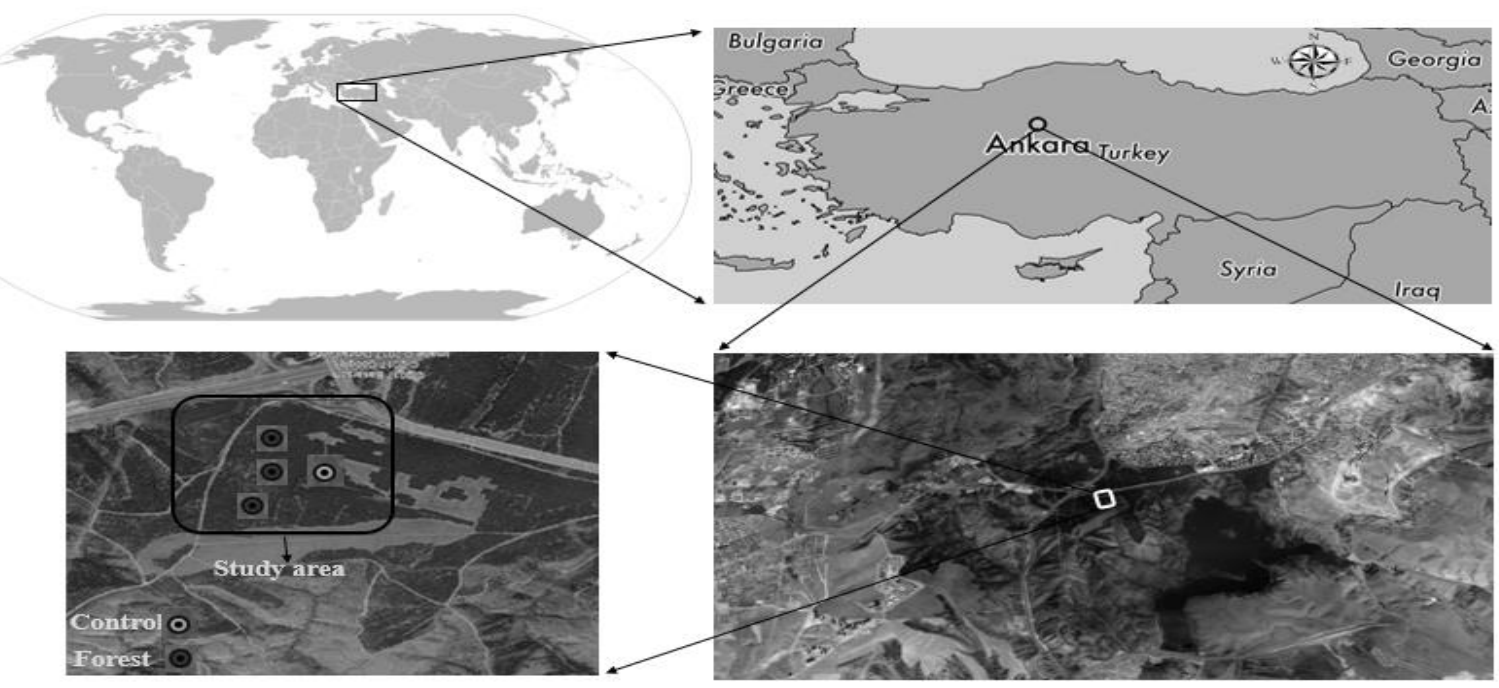

Figure 3 Study area location and sample points

\section{Material and Method}

\section{Location}

The study area is located in the Central Anatolia Region of Turkey in Gölbaş1/Ankara province. (39 50'23" N - 32०48'28" E, Elevation: 1070m asl) (Figure 3). The main aspect of the is the Northwest (NW) average terrain slope is 5\%. Study area is approximately $11.5 \mathrm{~km}$ far away from center of the Ankara province.

\section{Climate}

According to the climate data of the last 89 years, the average annual temperature is $11.9^{\circ} \mathrm{C}$ and the annual total precipitation is $387.2 \mathrm{~mm}$. According to Walter (1975) climate diagram, study area is included in semi-arid regions (Figure 4). There is water shortage in the environment and a dry period occurs from June to October throughout the year. In addition, the study area is classified as "arid" according to Aydeniz climate classification, "Among step and humid" according to DeMartonne and "B1, semi dry" according to Thornthwaite method (MGM, 2018).

\section{Forest Stand Structure}

The study area has been successfully planted in the 1970s with the species of Anatolian black pine [(Pinus nigra Arn. subsp. pallasiana (Lamb.) Holmboe]. The geological structure is from the upper Paleocene period and parent material is Lime and lime stone. Soil is textured generally clay in both land use types (forested and barren area). The canopy closure of the forested area is over $50 \%$. Forest stand intensity: 775 tree/ha, Mean $\mathrm{DBH}$ is $19.5 \mathrm{~cm}$; Mean height is $10.1 \mathrm{~m}$; Stand age is approximately 40 years old (Figure 5).

\section{Data Collection}

Soil sampling: Three forested plots and one barren (control) plot $(50 \mathrm{~m} \times 50 \mathrm{~m})$ were selected in the study area. Totally 48 soil sample in two soil depth level $(0-20 \mathrm{~cm}$, $20-50 \mathrm{~cm})$ were collected from forest in different crown closure $[(60 \%, 80 \%, 90 \%),(36$ soil sample) $]$ and barren area [(12 soil sample) (Figure 6)]. 


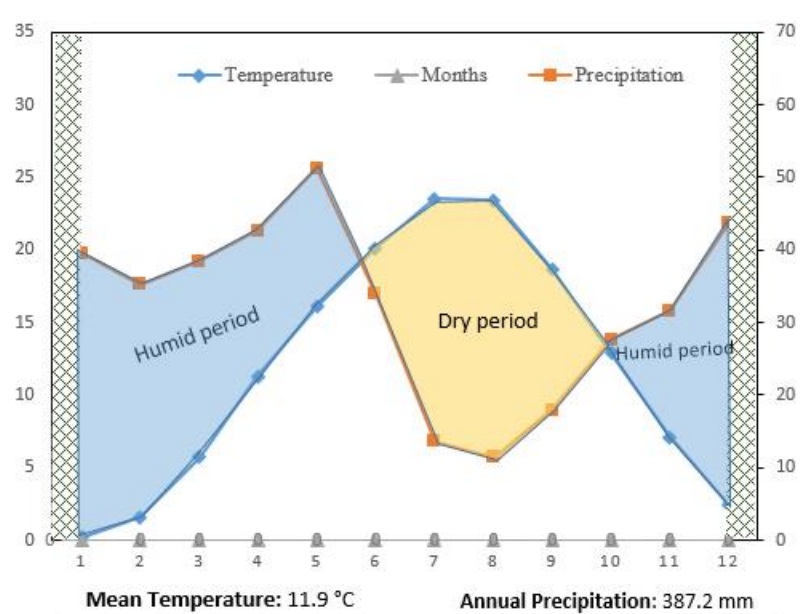

Figure 4 Walter climate diagram of research area (19272016)
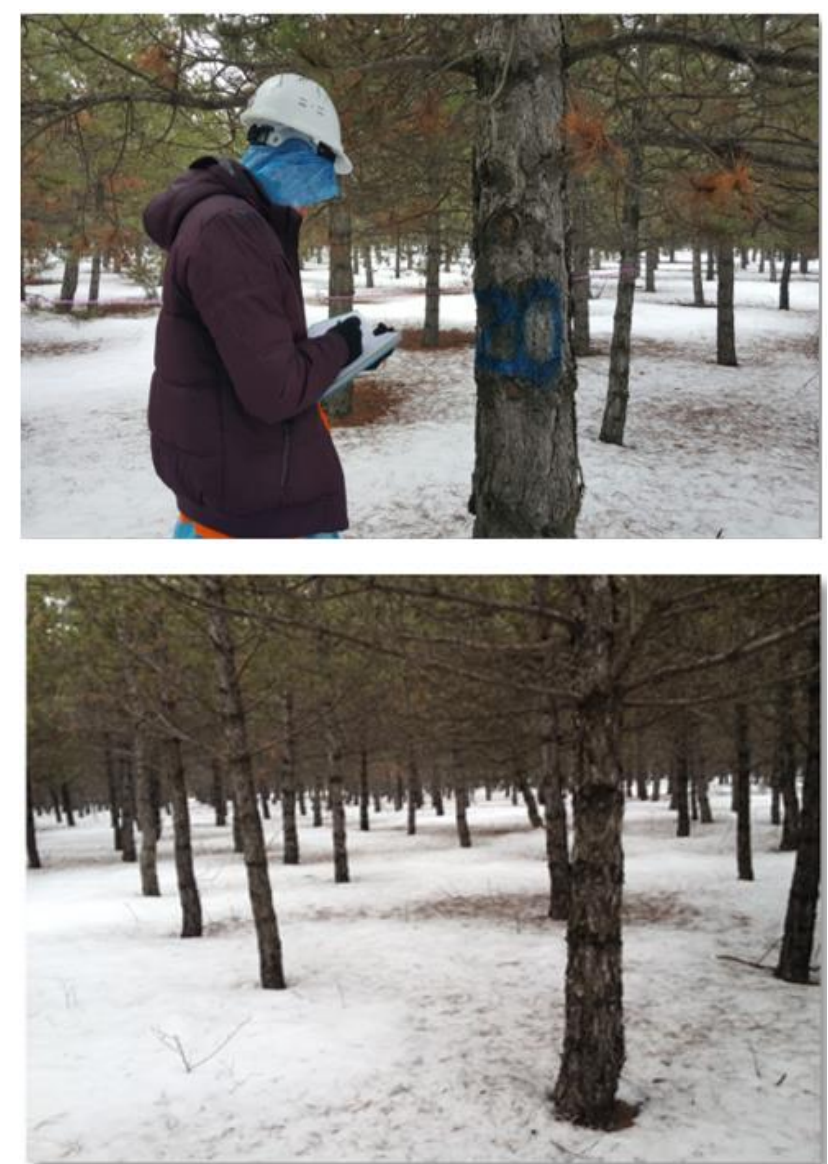

Figure 5 Forest stand structure of study area
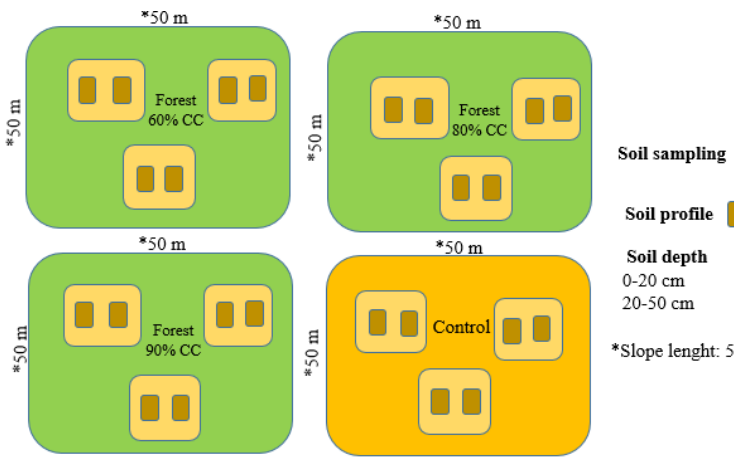

$20-50 \mathrm{~cm}$

*Slope lenght: 50 meters

Figure 6 Soil sampling pattern of the study area

Surface stoniness (\%), slope (\%), aggregate classes etc. were assessed in each study site respectively (Kartieranleitung, 1994). In soil analysis, sieved $(<2.0$ $\mathrm{mm})$ soil particles were used. Permeability class, Field Capacity (\%), Wilting Point (\%), Saturation (\%), Available Water Holding Capacity $(\mathrm{cm} / \mathrm{cm})$, Saturated Hydraulic Conductivity $\left(\mathrm{cm} / \mathrm{hr}\right.$.), Bulk Density $\left(\mathrm{gr} / \mathrm{cm}^{3}\right)$ were determined according to Saxton et al. (1986). Soil texture was determined according to bouyoucos (1962) hydrometer method. Soil $\mathrm{pH}\left(\mathrm{H}_{2} \mathrm{O}\right)$ was determined by digital $\mathrm{pH}$ meter (Gülçur, 1974) and the organic matter content by the Walkley-Black, wet oxidation method (Allison, 1965).

Soil loss estimation by ABAG (Allgemeine Boden Abtrags Gleichung): In this study, ABAG (Allgemeine Boden Abtrags Gleichung) (Schwertmann et al. 1990) simulation model modified from USLE [(Universal Soil Loss Equation) (Wischmeier and Smith, 1978)] was used in soil loss accounting (1).

$$
\mathrm{A}=\mathrm{K} \times \mathrm{R} \times \mathrm{L} \times \mathrm{S} \times \mathrm{C} \times \mathrm{P}
$$

Where $\mathrm{A}$ is the average annual soil loss ( $\mathrm{t} / \mathrm{ha}$ per year), $\mathrm{K}$ the soil erodibility factor, $\mathrm{R}$ the rainfall erosivity factor, LS slope and slope length factor, $\mathrm{C}$ the cover management factor and $\mathrm{P}$ is the supporting practice factor. Climate erosivity is represented by $\mathrm{R}$ and can be estimated from the rainfall intensity and ' $\mathrm{R}$ ' value was calculated based on erosion index map (Doğan and Gücer, 1976) and ' $K$ ', 'LS', 'C', 'P' values were calculated according to ABAG (Schwertmann et al. 1990)

Soil loss equation values in our study that $\mathrm{R}$ value; 25.0, P factor; 1.0, L; 50 meters, S; 5\%, LS factor; 0.624 were fixed at all plots respectively. However, ' $\mathrm{C}$ ' factor had different value depend on land use and crown closures (barren area:0.10, 60\% CC:0.03, 80\% CC:0.02, $90 \%$ CC:0.01). And K factor calculated based on soil properties in each sample plots.

\section{Statistical Analysis}

Statistical analyses were performed with SPSS version 23.0 software package (SPSS Institute Inc., Chicago, IL, USA, 2016). Soil properties and soil loss amount relations among the land use group were determined by Student's $t$ -test for normally distributed values and by MannWhitney U-test for nonparametric and Correlations were tested by Pearson's correlation coefficient. Results are expressed as means $\pm \mathrm{SE}$ (Standard error). Statistical significance was defined as $\mathrm{P}$ was $<0.05$ and $<0.01$.

\section{Results and Discussion}

An overall evaluation, in a period of 40 years, afforestation efforts have significantly $(\mathrm{P}<0.05)$ affected soil loss in a unit area and soil hydro-physical properties such as soil texture (sand, silt and clay ratio), bulk density $\left(\mathrm{gr} / \mathrm{cm}^{3}\right)$, field capacity $(\%)$, wilting point $(\%)$, saturation (\%), available water holding capacity (\%) and saturated hydraulic conductivity $(\mathrm{cm} / \mathrm{hr}$.) in both topsoil $(0-20 \mathrm{~cm})$ and subsoil $(20-50 \mathrm{~cm})$ and soil acidity $(\mathrm{pH})$ was affected. Soil organic matter [(\%) (in except subsoil)] also was affected. We found that soil loss amounts in planted area, 5.5 times less than barren area (forest: $0.036 \mathrm{t} / \mathrm{ha}$, 
barren: $0.192 \mathrm{t} / \mathrm{ha})$ at topsoil $(0-20 \mathrm{~cm})$ and topsoil+subsoil [(0-50 cm) (Figure 7$)]$. And Soil loss amounts (topsoil+subsoil) significantly correlated (at 0.01 and 0.05 levels) with almost all soil properties (Table 1).

\section{Effects of Afforestation on Soil Loss}

The soil loss in a region can vary depend on land use, soil characteristics and local ecological conditions, but the rainfall regime and the climatic factors play the most important role. Average annual soil loss in planted area was found approximately 0.036 t/ha (Figure 7) and similar result $(0.04 \mathrm{t} / \mathrm{ha})$ was found by Chirino et. al. (2001) in semi-arid region. Hacisalihoglu et al (2017) and
Breetzke et al (2013) found soil loss as $0.6 \mathrm{t} / \mathrm{ha} / \mathrm{yr}$. for plantation area in semi-humid region. It is indicating that ' $\mathrm{R}$ ' factor one of the components of soil loss equation play an important role according to different climatic conditions. So, soil loss amounts tend to increase from arid region to humid region. In our study, also ' $\mathrm{C}$ ' factor played important role in soil loss due to barren and forested area had different ' $C$ ' value in soil loss equation. In previous researches indicated that the " $C$ " factor significantly affected surface runoff, erodibility and soil erosion (Zhao et al 2012; Kuok et al. 2013; Karamage et al 2016).

Table 1 Correlation in soil variables of study area

\begin{tabular}{|c|c|c|c|c|c|c|c|c|c|c|c|c|c|}
\hline \multicolumn{2}{|c|}{ MP } & $\mathrm{Sn}$ & $\mathrm{Si}$ & $\mathrm{Cy}$ & $\mathrm{O}$ & $\mathrm{pH}$ & $\mathrm{F}$ & $\mathrm{W}$ & St & AW & $\mathrm{SH}$ & $\mathrm{BD}$ & AS \\
\hline \multirow{2}{*}{ Sn } & $\mathrm{P}$ & 1 & & & & & & & & & & & \\
\hline & $S$ & & & & & & & & & & & & \\
\hline \multirow{2}{*}{$\mathrm{Si}$} & $\mathrm{P}$ & -.144 & 1 & & & & & & & & & & \\
\hline & $\mathrm{S}$ & .330 & & & & & & & & & & & \\
\hline \multirow{2}{*}{$\mathrm{Cy}$} & $\mathrm{P}$ & $-.922 * *$ & -.250 & 1 & & & & & & & & & \\
\hline & $\mathrm{S}$ & .000 & .087 & & & & & & & & & & \\
\hline \multirow{2}{*}{$\mathrm{O}$} & $\mathrm{P}$ & 0.250 & -.164 & -.181 & 1 & & & & & & & & \\
\hline & $\mathrm{S}$ & .087 & .267 & .219 & & & & & & & & & \\
\hline \multirow{2}{*}{$\mathrm{pH}$} & $\mathrm{P}$ & .196 & $.567 * *$ & $-.413^{* *}$ & $-.453 * *$ & 1 & & & & & & & \\
\hline & $\mathrm{S}$ & .181 & .000 & .003 & 0.001 & & & & & & & & \\
\hline \multirow{2}{*}{$\mathrm{F}$} & $\mathrm{P}$ & $-.890 * *$ & $-.294 *$ & $.985 * *$ & -.146 & $-.479 * *$ & 1 & & & & & & \\
\hline & $S$ & .000 & .043 & .000 & .323 & .001 & & & & & & & \\
\hline \multirow{2}{*}{ W } & $\mathrm{P}$ & $-.883 * *$ & $-.309 *$ & $.984 * *$ & -.111 & $-.496 * *$ & $.998 * *$ & 1 & & & & & \\
\hline & $\mathrm{S}$ & .000 & .033 & .000 & .452 & .000 & .000 & & & & & & \\
\hline \multirow{2}{*}{ St } & $\mathrm{P}$ & $-.951 * *$ & -.072 & $.959 * *$ & -.082 & $-.396 * *$ & $949 * *$ & $.952 * *$ & 1 & & & & \\
\hline & $\mathrm{S}$ & .000 & .625 & .000 & .580 & .005 & .000 & .000 & & & & & \\
\hline \multirow{2}{*}{ AW } & $\mathrm{P}$ & $-.292 *$ & $-.449 * *$ & $.461 * *$ & -.101 & $-.606 * *$ & $.520 * *$ & $.496 * *$ & $.360 *$ & 1 & & & \\
\hline & $\mathrm{S}$ & .044 & .001 & .001 & .494 & .000 & .000 & .000 & .012 & & & & \\
\hline \multirow{2}{*}{ SH } & $\mathrm{P}$ & $.641 * *$ & $.510 * *$ & $-.827 * *$ & .151 & $489 * *$ & -.870 & $-.867 * *$ & $-.708^{* *}$ & $-.568 * *$ & 1 & & \\
\hline & $\mathrm{S}$ & .000 & .000 & .000 & .305 & .000 & .000 & .000 & .000 & .000 & & & \\
\hline \multirow{2}{*}{$\mathrm{BD}$} & $\mathrm{P}$ & $.956 * *$ & .073 & $-.964 * *$ & .103 & $.389 * *$ & $-.955 * *$ & $-.956 * *$ & $-.997 * *$ & $-.361 *$ & $.717 * *$ & 1 & \\
\hline & $\mathrm{S}$ & .000 & .622 & .000 & .488 & .006 & .000 & .000 & .000 & .012 & .000 & & \\
\hline \multirow{2}{*}{ AS } & $\mathrm{P}$ & $350 *$ & $.642 * *$ & $-.593 * *$ & -.269 & $.869 * *$ & $-.637 * *$ & $-.653 * *$ & $-.537 * *$ & $-.749 * *$ & $.636 * *$ & $.530 * *$ & 1 \\
\hline & $\mathrm{S}$ & .015 & .000 & .000 & .064 & .000 & .000 & .000 & .000 & .000 & .000 & .000 & \\
\hline
\end{tabular}

MP: Measured Parameters, Sn: Sand (\%), Si: Silt (\%), Cy: Clay (\%), O: OM (\%), F: FC (\%), W: WP (\%), St: Saturation (\%), AW: AWHC (cm/cm), SH: Sat. Hyd. Conduct. (cm/hr), BD: Bulk Density (gr/cm3), AS: A-Soil Loss $(0-50 \mathrm{~cm})(\mathrm{t} / \mathrm{ha} / \mathrm{yr})$, P: Pearson Cor., S: Sig. (2-tailed)

Soil loss (t/ha/yr)

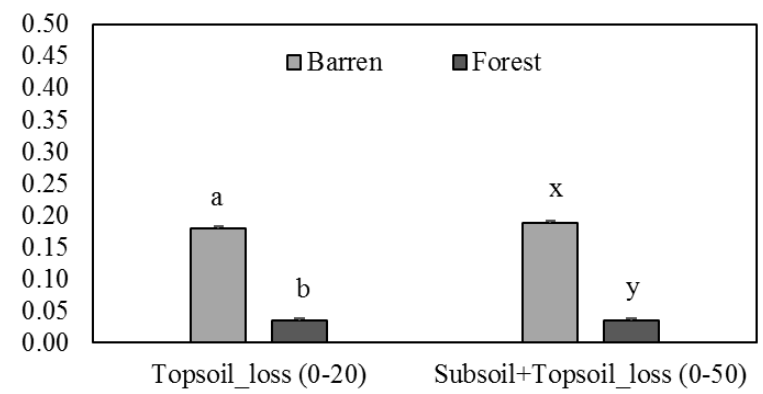

Figure 7 Soil loss amounts according to land use groups (Forest $\mathrm{n}=36$, Barren $\mathrm{n}=12, \mathrm{P}<0.01$, Mean $\pm \mathrm{SE}$ )

\section{Effects of Plantation on Soil Hydro-Physical Properties}

Generally, soil texture properties such as silt, clay and sand values are changed in a long period under the land use changes (Szujecki, 1996). However, in our study, black pine plantation significantly affected $(\mathrm{P}<0.01)$ the soil texture in a semi-arid region such as short period of 40 years (Figure 8). The main reason for this is caused by climatic conditions (Podrázský et al, 2015). A study reported (Hacisalihoglu et al 2017) that soil texture wasn't affected in a semi-humid region in the same short period.

In our study, some important hydrological soil properties such as field capacity (\%), wilting point $(\%)$ saturation $(\%)$, Available Water holding capacity $(\mathrm{cm} / \mathrm{cm})$ and saturated hydraulic conductivity $(\mathrm{cm} / \mathrm{hr}$.) significantly $(\mathrm{p}<0.01)$ affected by black pine plantation (Figure 9-10). In conducted studies, it is reported that plant cover and land use regime significantly affected soil moisture conditions (Deng et al. 2015).

In Terrestrial ecosystems, soil organic matter, soil acidity and bulk density reflect remarkable variation according to land use changes (Hacisalihoglu et al 2017; Gol, 2009). In our study, black pine plantation significantly $(\mathrm{P}<0.05)$ affected the soil acidity, bulk density in top and subsoil. Also, organic matter in topsoil significantly $(\mathrm{P}<0.05)$ affected but subsoil organic matter wasn't significantly (P>0.05) affected (Figure 11). 

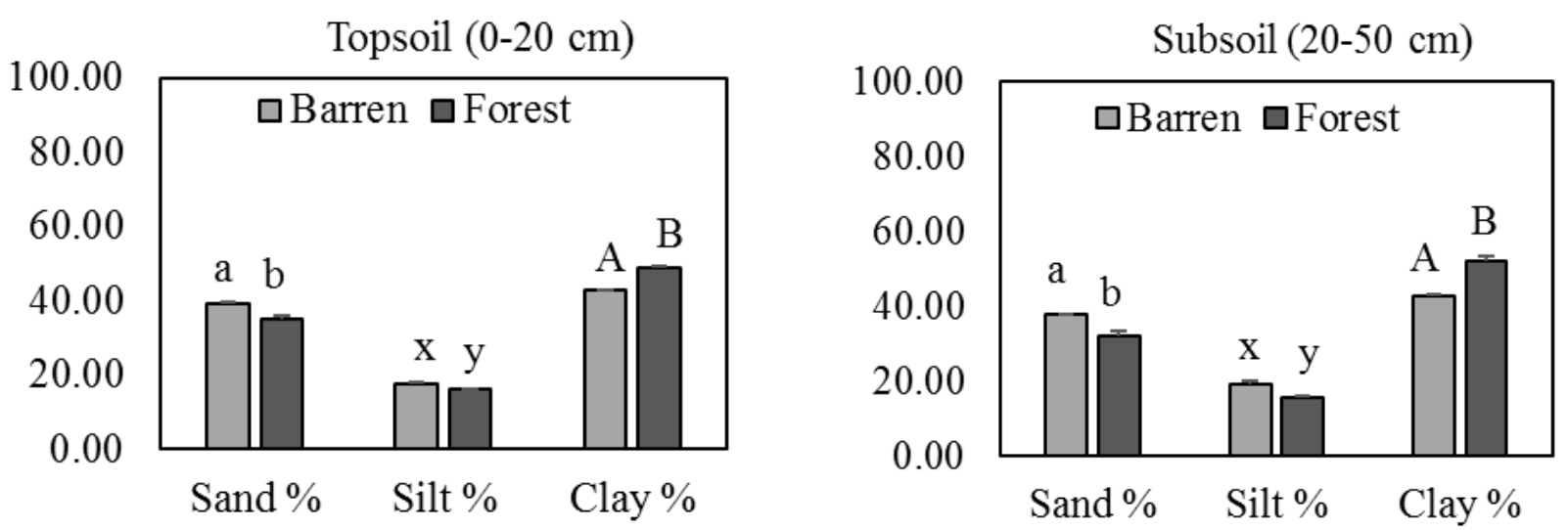

Figure 8 Effects of plantation on soil texture depend on soil depth (Forest $n=18$, Barren $n=6, P<0.01$, Mean \pm SE)
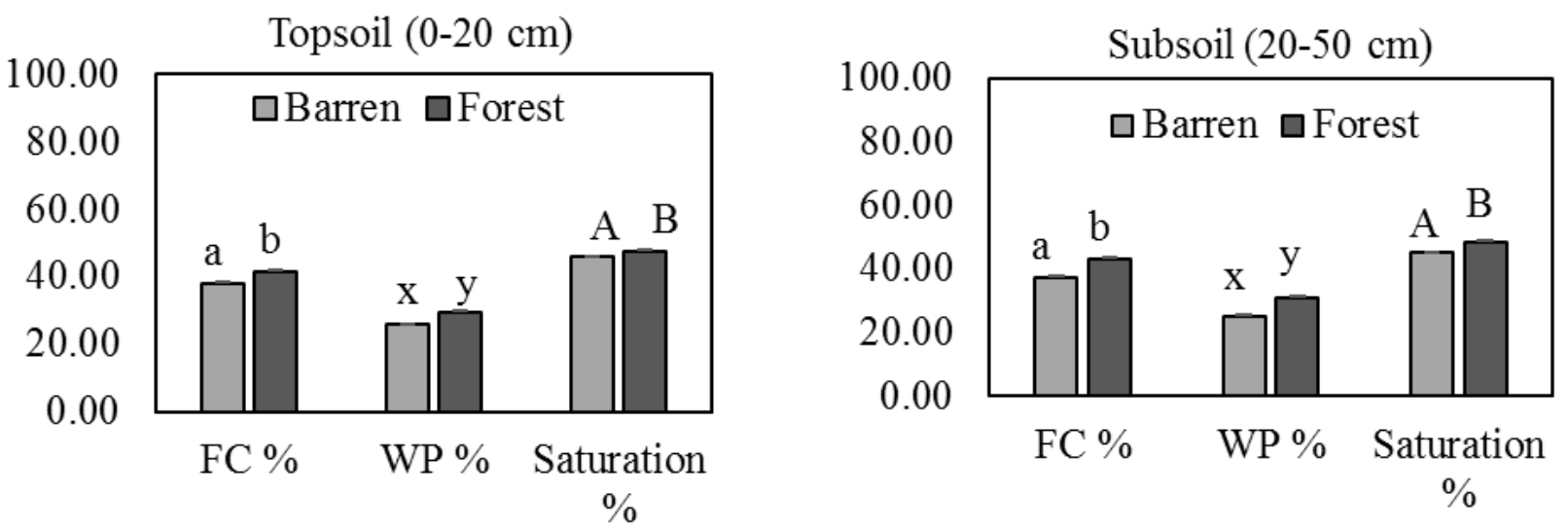

Figure 9 Effects of plantation on soil moisture characteristics (Forest $n=18$, Barren $n=6, P<0.01$, Mean \pm SE)
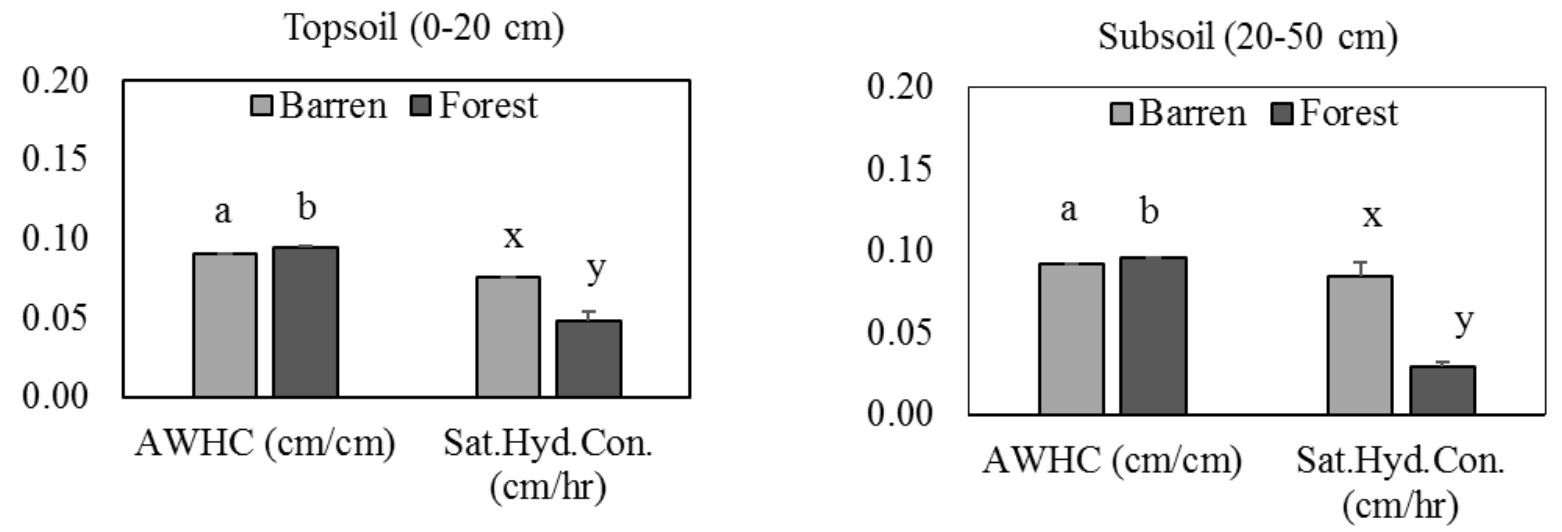

Figure 10 Effects of plantation on AWCH and Sat. Hyd. Con. (Forest n=18, Barren n=6, P<0.05, Mean \pm SE)
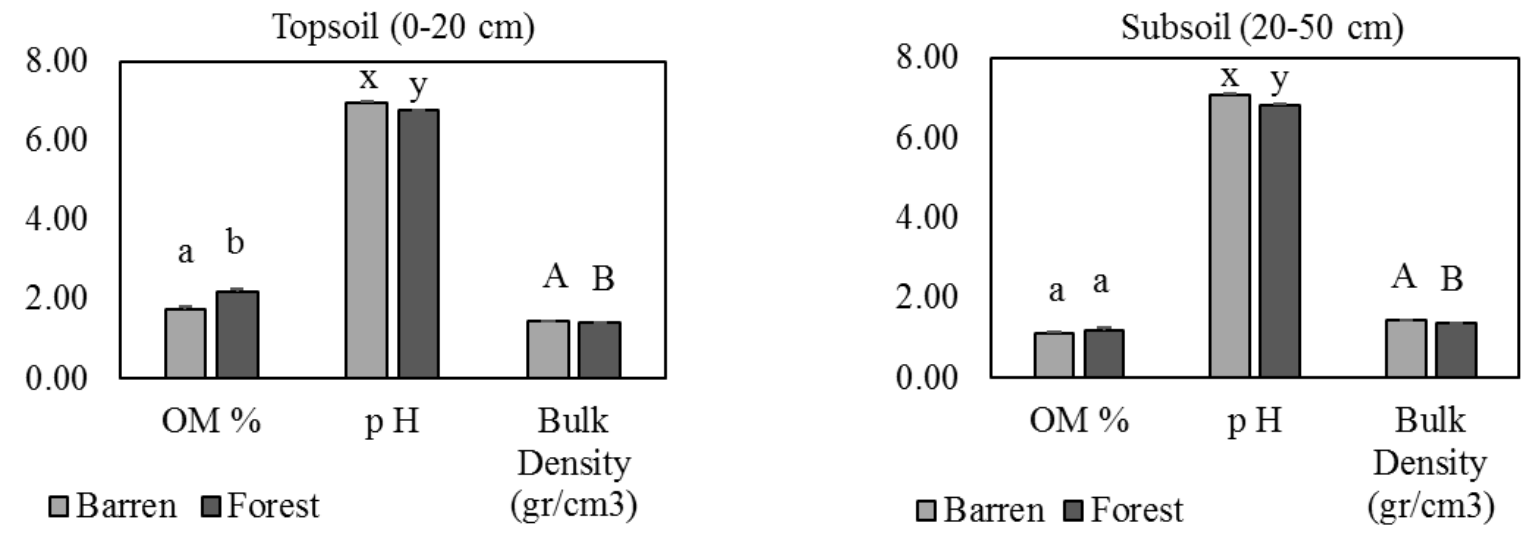

Figure 11 Effects of plantation on some important soil hydrological properties depend on soil depth (Forest $\mathrm{n}=18$, Barren $\mathrm{n}=6, \mathrm{P}<0.05$, Mean $\pm \mathrm{SE}$ ) 


\section{Conclusions}

Vegetation factor (C) which is one of the most important components of the soil loss equation, has been significantly affected by Anatolian black pine plantation in a short period of 40 years and thus it was a variable to reduce to soil loss. Low slope and rainfall values significantly reduced the amount of soil loss in the study area. If this study area were in a semi-humid and humid region (Rize province, Turkey), the total soil loss in the forest and in the barren area would be about 16 times higher, under the similar soil-vegetation-slope condition.

\section{Acknowledgements}

A part of this paper has been presented at International Forestry and Environment Symposium on "Climate Change and Tree Migration": November 07-10, 2017. Author would like to thank undergraduate student Yusuf Kürşat Kaya, graduate student Hakan Karadağ and Research assistant Uğur Kezik for their valuable field and laboratory efforts.

\section{References}

Allison LE. 1965. Organic Carbon: Walkley-Black Method. In: Methods of Analysis. Agronomy Monographs No: 9, Part 2. American Society Agronomy, Madison, Wisconsin, USA, pp.1367-1378.

Breetzke GD, Koomen E, Critchley WRS. 2013. GIS-Assisted Modelling of Soil Erosion in a South African Catchment: Evaluating the USLE and SLEMSA Approach, Water Resources Planning, Development and Management, Prof. Ralph Wurbs (Ed.), InTech, DOI: 10.5772/52314.

Bouyoucos GJ. 1962. Hydrometer Method Improved for Making Particle Size Analyses of Soils. Agronomy Journal, 54: 464465. Doi:10.2134/agronj1962.00021962005400050028x

Chirino E, Sanchez JR, Bonet A, Bellot J, 2001. Effects of afforestation and vegetation dynamics on soil erosion in a semi-arid environment (SE Spain). Transactions on Ecology and the Environment, 46: 239-248. www.witpress.com (Last accessed 5April 2018)

Constanza R, Jorgensen SE. 2002. Understanding and Solving Environmental Problems in the 21st Century. Toward a New, Integrated Hard Problem Science. Imprint: Elsevier Science pp. University of Maryland Institute for Ecological Economics, Solomons, MD 20688-0038, USA. ISBN: 9780-08-044111-5.

Cornelis W.M. 2006. Hydroclimatology of wind erosion in arid and semiarid environments. Chapter 9. Dryland Ecohydrology, D'Odorico and A. Porporato (eds.), 141-159. Springer. Printed in the Netherlands. Print ISBN: 978-14020-4259-1.

Çetinkaya D, Deligöz A. 2012. Anadolu karaçamı (pinus nigra arn. Subsp. Pallasiana (lamb.) Holmboe)'nda yerinde kök kesimlerinin fidan morfolojisi üzerindeki etkisi. Bartın Orman Fakültesi Dergisi, 14 (Özel Say1): 49-58.

ÇEM. 2017. Kurak ve yarı kurak alanlarda ağaçlandırma ve rehabilitasyon rehberi. Orman $\mathrm{Ve} \mathrm{Su}$ Işleri Başkanliği Çölleşme Ve Erozyonla Mücadele Genel Müdürlüğü. Erozyon Kontrolü Daire Başkanliği, Mart, Ankara. Available from: http://www.cem.gov.tr/erozyon/anasayfa (Accessed 5April 2018).

Deng L, Yan W, Zhang Y, Shangguan Z. 2015. Severe depletion of soil moisture following land-use changes for ecological restoration: Evidence from northern China. Forest Ecology and Management, 366: 1-10. Available from: https://doi.org/10.1016/j.foreco.2016.01.026 (Accessed 5 April 2018).
Doğan O, Güçer C. 1976. Su erozyonunun nedenleri oluşumu ve üniversal denklem ile toprak kayiplarinin saptanmasi. Merkez Topraksu Araştırma Enstitüsü Müdürlüğü Yayınları, Genel Yayın No: 41, Teknik Yayın No: 224, Ankara.

FAO 1963. Tree Planting Practices for Arid Zones, Food and Agriculture Organization of The United Nations, Rome. Available from: www.fao.org/docrep/012/al040e/al040e00.pdf (Accessed 5 April 2018).

Feng H.H., Liu Y.B. 2015. Combined effects of precipitation and air temperature on soil moisture in different land covers in a humid basin. J. Hydrol., 531: 1129-1140. Available from: $\quad$ https://doi.org/10.1016/j.jhydrol.2015.11.016 (Accessed 5 April 2018).

Guo Z, Shao M. 2013. Impact of afforestation density on soil and water conservation of the semiarid Loess Plateau, China. Journal of Soil and Water Conservation 68(5):401410. Doi: 10.2489/jswc.68.5.401. Avaliable from: http://www.jswconline.org/content/68/5/401.short (Accessed 5 April 2018)

Gülçur F. 1974. Toprağın Fiziksel ve Kimyasal Analiz Metodları. İstanbul: Orman Fakültesi (Yay. No.201, İ.Ü. Yay. No.1970).

Gol C. 2009. The effects of land use change on soil properties and organic carbon at Dagdami river catchment in Turkey. $\mathrm{J}$ Environ Biol., 30 (5 Suppl):825-30.

Hacisalihoglu S, Misir M, Misir N, Yücesan Z, Oktan E, Gümüş S, Kezik U. 2017. The Effects of Land Use Change on Soil Loss and Carbon Stock Amounts, Fresenius Environmental Bulletin, 26:1-13.

Kakaire J, Makokha GL, Mwanjalolo M, Mensah AK, Emmanuel M. 2015. Effects of Mulching on Soil HydroPhysical Properties in Kibaale Sub-catchment, South Central Uganda. Applied Ecology and Environmental Sciences, 3 (5): 127-135. Doi: 10.12691/aees-3-5-1.

Karamage F, Zhang C, Kayıranga A, Shao H, Fang X, Ndayisaba F, Nahayo L, Mupenzi C, Tian G. 2016. USLEBased assessment of soil erosion by water in the Nyabarongo River Catchment, Rwanda. Int. J. Environ. Res. Public Health, 13: 835. Doi: 10.3390/ijerph13080835.

Kartieranleitung BB. 1994. Bodenkundlische Kartieranleitung, 4. Auflage E. Kunstoffeinband. ISBN 978-3-510-95920-4.

Kezik U. Kocaçınar F. 2014. Kurak ve Yarı-Kurak Bölgelerde Yayılış Gösteren Quercus branthii L. Baltalıklarında Seyreltmenin Su Potansiyeli ve Sürgün Durumu Üzerine Etkisi. II. Ulusal Akdeniz Orman ve Çevre Sempozyumu. Akdeniz ormanlarının geleceği: Sürdürülebilir toplum ve çevre Isparta-Turkey, 22-24 September, Suleyman Demirel University, pp:117-127.

Kocaçınar F. Abacı AA, Kezik U. 2010. Kurak ve Çorak Alanların Rehabilitasyonunda Kullanılabilecek C3 ve C4 Bitkilerde Ekofizyolojik Parametreler. III. Ulusal Karadeniz Ormancilık Kongresi, Artvin-Turkey, 20- 22 May, Artvin Coruh University. pp (III):1144-1156.

Kreidenweis U, Humpenöder F, Stevanović M, Bodirsky BL, Kriegler E, Lotze-Campen H, Popp A. 2016. Afforestation to mitigate climate change: impacts on food prices under consideration of albedo effects. Environ. Res. Lett. 11: 085001. Doi:10.1088/1748-9326/11/8/085001.

Kuok Kelvin KK, Mah Darrien YS, Chaiu PC. 2013. Evaluation of $\mathrm{C}$ and $\mathrm{P}$ factors in universal soil loss equation on trapping sediment: Case study of Santubong River. Journal of Water Resource and Protection, 5:1149. Doi: 10.4236/jwarp.2013.512121.

Li L, Wang Y, Liu C. 2014. Effects of land use changes on soil erosion in a fast-developing area. Int. J. Environ. Sci. Technol. 11, 1549-1562. Avaliable from https://doi.org/10.1007/s13762-013-0341-x (Accesses 5 April). 
Marquiss M. 2006. AFFORNORD ‘Summing up' of ecosystem biodiversity sessions: The effects of afforestation on ecosystem biodiversity. In: Proceedings of the AFFORNORD conference, Reykholt, Iceland, June 18-22. TemaNord 2007: 508. Eds: Halldorsson, G., Oddsdottir, ES. And Eggertsson, O. 167-169. ISBN 978-92-893-1718-4.

MGM 2018. (Turkish State Meteorological Service) Turkey. Avaliable online: https://www.mgm.gov.tr/iklim/iklimsiniflandirmalari.aspx?m=ANKARA (Accessed 09 January 2018).

Pimentel D, Burgess M. 2013. Soil Erosion Threatens Food Production. College of Agriculture and Life Sciences, Cornell University, Ithaca, NY 14853, USA. Agriculture, 3(3): 443-463.

Podrázský V, Holubík O, Vopravil J, Khel T, Moser WK, Prknová H. 2015. Effects of afforestation on soil structure formation in two climatic regions of the Czech Republic. Journal of Forest Science, 61 (5): 225-234. Doi: 10.17221/6/2015-JFS.

Rebeca Vásquez-Méndez, Eusebio Ventura-Ramos, Klavdia Oleschko, Luis Hernández-Sandoval and Miguel Angel Domínguez-Cortázar 2011. Soil Erosion Processes in Semiarid Areas: The Importance of Native Vegetation, Soil Erosion Studies, Dr. Danilo Godone (Ed.), ISBN: 978-953307-710-9. https://www.intechopen.com/books/soil-erosionstudies/soil-erosion-processes-in-semiarid-areas-theimportance-of-native-vegetation (Accessed 5 April 2018).

Saxton KE, Rawls WJ, Romberger JS, Papendick RI. 1986. Estimating generalized soil-water characteristics from texture. Soil Sci. Soc. Amer. J., 50 (4): 1031. Doi: 10.2136/sssaj1986.03615995005000040039x.

Schwertmann U., Vogl W., Kainz M. 1990. Bodenerosion durch Wasser: Vorhersage des Abtrags und Bewertung von Gegenmassnahmen, Ulmer Verlag, Stuttgart. 64 Seiten, 18 Tabellen, 8 Abbildungen, 32, - DM. ISBN 38001-3081-5. Avaliable from: https://doi.org/10.1002/jpln.19901530111 (Accessed 5 April 2018).

Szujecki A. 1996. Ekologiczne aspekty odtwarzania lasu na glebach porolnych. Prace IBL, ser. B, 27:47-55. Avaliable from: http://agro.icm.edu.pl/agro/element/bwmeta1.element.agro2ee9e84c-2555-42f8-867a-aa4d5475d2b5 (Accessed 5 april 2018)
IUCN (International Union for Conservation of Nature). 2015. Land Degradation and Climate Change The multiple benefits of sustainable land management in the drylands. Technical Reports. CH-1196 Gland, Switzerland. Avaliable from:

https://www.iucn.org/sites/dev/files/import/downloads/land_ degradation_issues_brief_cop21_031215.pdf (Accessed $\overline{5}$ April 2018).

Ürgenç S. 1998. Ağaçlandırma Tekniği, Yenilenmiş ve Genişletilmiş İkinci Baskı İ.Ü.Orman Fak.Yayınları, İ.Ü. Rektörlüğ̈̈ Yayın No:3994, Orman Fakültesi, İstanbul Yayın no: 441, ISBN. 975-404- 446-5.

Walter H, Harnickell E, Mueller Domboi D. 1975. ClimateDiagram Maps of The Individual Continents And The Ecological Climatic Regions of The Earth. Berlin: SpringerVerlag. 36p. with 9 maps. ISBN: 3-540-07065-6.

Wischmeier WH, Smith DD. 1978. Predicting Rainfall Erosion Losses, A Guide to Conservation Planning, USDA, Supersedes Agriculture Handbook No.282, Washington. Avaliable https://naldc.nal.usda.gov/download/CAT79706928/PDF (Accessed 5 April 2018).

Wu J. 2008. Land Use Changes: Economic, Social, and Environmental Impacts. Choices, 23 (4):6-10. Avaliable from:

https://www.fs.fed.us/pnw/pubs/journals/pnw_2008_wu001. pdf (Accessed 5April 2018).

Xiang Y, Cheng M, Huang Y, An S, Darboux F. 2017. Changes in Soil Microbial Community and Its Effect on Carbon Sequestration Following Afforestation on the Loess Plateau, China. Int. J. Environ. Res. Public Health, 14 (8):948. Doi: 10.3390/ijerph14080948. Avaliable from: https://www.ncbi.nlm.nih.gov/pmc/articles/PMC5580650/ (Accessed 5 April 2018).

Zhao WW, Fu BJ, Chen LDA. 2012. Comparison between soil loss evaluation index and the C-factor of RUSLE: a case study in the Loess Plateau of China. Hydrol. Earth Syst. Sci., 16: 2739-2748. Avaliable from: https://doi.org/10.5194/hess-16-2739-2012 (Accessed 5 April 2018)

Zhiyanski M, Glushkova M, Ferezliev A, Menichetti L, Leifeld L. 2015. Carbon Storage and Soil Sroperty Shanges Sollowing Afforestation in Mountain Ecosystems of the Western Rhodopes, Bulgaria. iForest, 9: 626-63. Doi: 10.3832/ifor1654-009. Avaliable from: http://iforest.sisef.org/contents/?id=ifor1654-009 (Accessed 5 April 2018). 